\title{
Detection of Salmonella In Some Red and White Frozen Meat Obtained From Local Market.
}

\author{
Sudad J. Mohammed
}

BVM\&S, MSc

\begin{abstract}
:
Background: Salmonella spp. are one of the most frequently reported causes of bacterial foodborne outbreak in the world.

Objective: This study has been conducted to detect salmonella as a major public health problem worldwide.

J Fac Med Baghdad 2015; Vol.57, No.1 Received Dec 2014 Accepted Fab.2015

Methods: A total of 12 samples including 8 white meat (chicken) and 4 red meat (beef) samples were collected randomly from each sample; $25 \mathrm{gr}$ was separated and treated with $225 \mathrm{ml}$ of buffered peptone water, incubated at $37 \mathrm{C}^{\circ}$ and $42 \mathrm{C}^{\circ}$ for 24 hours. Samples were streaked on selective enteric agar.

Result: Totally 4 out of 8 chicken meat and one out of 4 red meat samples were contaminated with Salmonella spp.

Conclusion: These results confirmed the previous findings stating the proper packaging of meat products can effectively decrease the rate of microbial contamination.

Key words: Salmonella, Meat product, local market.
\end{abstract}

\section{Introduction:}

Food borne diseases are one of the serious problems in developed and developing countries (1).Food borne disease is a widespread public health concern (2), More than 100 million people are afflicted by food borne and waterborne disease in the world (3). Salmonella is gram negative rod,mostly nonlactose fermenter, facultative anaerobic ,non-spore forming ,produce acid and gas from glucose, belonging to the family Enterobacteriace (4). Salmonella is one of the most commonly reported causes of food borne diseases in the European Union which show the highest disease burden on the population scale among bacterial food-borne pathogen (5).Salmonella contaminated in animal, entering the slaughterhouse can be attributed to several sources such as lairages, holding pens, transport, contaminated slaughterhouse equipment, floor and personnel, animal's viscera and processing facilities (6).Food borne salmonella infection is an important cause of morbidity and mortality worldwide. In this study detection of salmonella in some Red and White meat products obtained from market were investigated.

\section{Materials and Methods:}

Collection of samples:A total number of twelve meat samples including 8 white meat (Chicken) and 4 red meat (Beef) were obtained randomly from different food outlets during the period from March to June 2014..All these frozen samples were immediately transferred to the microbiology laboratory at Market Research and Consumer Production Center ,Baghdad. University , and kept at $-18 \mathrm{C}^{\circ}$ at deep freezer until

\footnotetext{
*Market Research \& Consumer Protection Center ,University of Baghdad.Email:Sudadjasm@yahoo.com
}

use(table1).

Prepration of samples $: 25 \mathrm{~g}$ of meat was taken from each meat production sample in sterile stomacher bag, grinded, was used to inoculate $225 \mathrm{ml}$ of peptone water and mixed with stomacher. Prepared samples were serially diluted $\left(10^{-6}\right)$ in sterile water and used to enumerated Salmonella spp. in specific culture medium.

Estimation of microbial count: This was carried out according to the methods described by (7and 8), which include the following methods:

a). Total Plate count : Diluted samples were cultured on plate count Agar by using one $\mathrm{ml}$ of each dilution $\left(10^{-6}\right)$ which added to petri-dish and incubated at $37 \mathrm{C}^{\circ}$ for 24 hours, colonies were counted.

b). Total coliform Bacteria: Diluted samples were plated onto Violet Red Bile agar by using one $\mathrm{ml}$ of $\left(10^{-6}\right)$ dilution which added to agar then another layer of medium was added to make anaerobic atmosphere. Plates were incubated at $37 \mathrm{C}^{\circ}$ for 24 hours, developed colonies were counted.

Isolation and Identification of Salmonella: Prepared samples with $\left(10^{-6}\right)$ dilution, $(0.1 \mathrm{ml})$ mixture was used to inoculate culture media, Salmonella Shigella agar (SSA) and Deoxycholate citrate agar (DCA) and incubated at $42 \mathrm{C}^{\circ}$ overnight. All suspected colonies were submitted to the standard biochemical reactions as Triple sugar iron (TSI). agar, Lysine decarboxylase (LIA), Urease ,Indole, methyl red, simmon citrate utilization to confirm whether they belong to Salmonella spp. ISO(2002)(9) .Many cultures of Salmoella may produce colonies with large, glassy block centers or many appear as almost completely block colonie. 
Table :( 1 ) The collected trade mark samples from Baghdad markets

\begin{tabular}{|c|c|c|c|c|c|c|}
\hline No & Sample & origin & Date of production & Date of expiry & Volume /gram & Notes \\
\hline 1 & Akpilic & Turkey & $2013 / 12 / 5$ & $2014 / 12 / 4$ & 900 & Frozen chicken Breast meat \\
\hline 2 & Halal & America & $2014 / 1 / 4$ & $2014 / 12 / 30$ & 1000 & Frozen chicken leg \\
\hline 3 & Sadia & Brazil & 2013/11/16 & 2014/11/15 & 1300 & Frozen chicken \\
\hline 4 & keskinoglu & Turkey & 2014/1/29 & $2014 / 12 / 1$ & 340 & Frozen Chicken Franks \\
\hline 5 & Banvit & Turkey & 2014/1/12 & $2015 / 1 / 11$ & 600 & Frozen Chicken wings \\
\hline 6 & Beyza & Turkey & 2013/10/9 & $2014 / 10 / 2$ & 900 & Frozen Chicken wings \\
\hline 7 & Al-Bayader & Jordan & $2014 / 1 / 7$ & $2015 / 1 / 6$ & 1400 & Frozen chicken \\
\hline 8 & Al-Faris & Iran & $2013 / 7 / 15$ & 2014/7/14 & 1600 & Frozen chicken \\
\hline 9 & Kirat-Baraka & Iraq & 2013/12/7 & 2014/11/6 & 688 & Frozen beef meat \\
\hline 10 & Halal - Al & India & $2013 / 8 / 1$ & $2014 / 7 / 30$ & 700 & Frozen beef meat \\
\hline 11 & Al-Anwar & India & 2013/12 & 2014/11 & 600 & Frozen beef meat \\
\hline 12 & Al-masria & Iraq & 2013/11/8 & $2014 / 10 / 30$ & 500 & Frozen beef meat \\
\hline
\end{tabular}

Statistical Analysis: Statistical significance was assessed by using least significant differences - LSD (T-test) P - value $<0.05$ was considered significance.

\section{Results:}

Table (1) shows the total plate count among samples of chickens and beef meat. High total count were recorded among sample frozen chicken(Halal) $44 \times 10^{5} \mathrm{CFu} / \mathrm{g}$ and low total count was recorded among sample frozen chicken wings (Banvit) $9 \times 10^{1} \mathrm{CFu} / \mathrm{g}$. While high total count were recorded among frozen beef meat (Al-Anwar) $28 \times 10^{5} \mathrm{CFu} / \mathrm{g}$, and the low total count was recorded among frozen beef meat (KuratBaraka) $9 \times 10^{2} \mathrm{CFu} / \mathrm{g}$ (Table2).High coliform bacteria count was recorded among chicken at frozen chicken leg (Halal) $23 \times 10^{3} \mathrm{CFu} / \mathrm{g}$ and low coliform bacteria count was recorded frozen chicken frank(keskinoglu) $6 \times 10^{1} \mathrm{CFu} / \mathrm{g}$. while High coliform bacteria count was recorded among frozen beef meat (Al-Anwar) $40 \times 10^{3} \mathrm{CFu} / \mathrm{g}$ and low bacterial beef was recorded among frozen beef meat (Al-Halal) $2 \times 10^{1} \mathrm{CFu} / \mathrm{g}$ (table3). Table(2and3) also show that culture method identified 4 samples of chicken as contaminated by Salmonella, while only one samples of beef meat sample was contaminated by Salmonella .

Table (2): Detection of Salmonella and Coliform bacteria from white frozen meat.

\begin{tabular}{ccccc}
\hline $\begin{array}{c}\text { No } \\
\text { A }\end{array}$ & $\begin{array}{c}\text { Sample of } \\
\text { Chicken }\end{array}$ & $\begin{array}{c}\text { Total Count } \\
\text { Bacteria CFu/g }\end{array}$ & $\begin{array}{c}\text { Total Coliform } \\
\text { Bacteria CFu/g }\end{array}$ & Salmonella \\
\hline 1 & akpilic & $12 \times 10^{2}$ & $9 \times 10^{1}$ & -- \\
\hline 2 & Halal & $44 \times 10^{5}$ & $23 \times 10^{3}$ & + \\
\hline 3 & Sadia & $32 \times 10^{3}$ & $11 \times 10^{2}$ & + \\
\hline 4 & keskinoglu & $41 \times 10^{2}$ & $6 \times 10^{1}$ & -- \\
\hline 5 & Banvit & $9 \times 10^{1}$ & $51 \times 10^{1}$ & -- \\
\hline 6 & Beyza & $15 \times 10^{4}$ & $36 \times 10^{2}$ & + \\
\hline 7 & Al-Bayader & $56 \times 10^{2}$ & $24 \times 10^{1}$ & -- \\
\hline 8 & Al-Faris & $47 \times 10^{3}$ & $35 \times 10^{2}$ & + \\
\hline
\end{tabular}

Table (3): Detection of Salmonella and Coliform bacteria from red frozen meat

\begin{tabular}{ccccc}
\hline $\begin{array}{c}\text { No } \\
\text { B }\end{array}$ & Sample of Beef & $\begin{array}{c}\text { Total Count } \\
\text { Bacteria } \\
\text { CFu/g }\end{array}$ & $\begin{array}{c}\text { Total Coliform } \\
\text { Bacteria } \\
\text { CFu/g }\end{array}$ & Salmonella \\
\hline 9 & Kirat-Baraka & $9 \times 10^{2}$ & $11 \times 10^{2}$ & -- \\
\hline 10 & Halal - Al & $98 \times 10^{4}$ & $2 \times 10^{1}$ & - \\
\hline 11 & Al-Anwar & $28 \times 10^{5}$ & $40 \times 10^{3}$ & + \\
\hline 12 & Al-masria & $31 \times 10^{3}$ & $21 \times 10^{2}$ & - \\
\hline
\end{tabular}

(--): Salmonella not detected

$(+)$ : Salmonella detected

\section{Discussion:}

Salmonellosis is one of the most important food borne diseases (10) .High prevalence of salmonella spp. In chicken and beef samples obtained in this study was similar to the previous studies $(11,12,13)$. Salmonella spp. infections are usually caused by handing on consuming contaminated food products (14).Cutting boards surfaces used for preparation of meat and equipment like meat grinds, mincers blenders are considered an important source of meat contamination by salmonella (15). Other study mentioned that tracks lairages, Slaughter line ,quartering, knives and surface of table are main sources of salmonella contamination of meat and meat products $(6,16)$. Contaminated water used to clean equipment and cutting slicing machines leading to cross-contamination especially if used with raw foods, handlers not practicing proper sanitation and faulty monitoring devices (17). 


\section{Conclusion:}

Meat and chicken products like, frozen chicken, beef meat ,buyer, minced meat are considered important sources of pathogenic salmonella spp. which causing server gastroenteritis in human good cooking of meat products before eating can tremendously decrease the incidence of salmonella.

\section{Reference:}

1-Higgs,J.D. Leaner Meat:An overview of the compositional changes in real meat over the last 20 years and how these have been achieved. Food ,Sci. and Technology.2000,14:22-26.

2-Towfeck,K.A;Abdel-Hafez,A.M.; andFeda,A.A.Microbiology Quality of Cured Meat in Jeddah Markets. J.K.A.U.Sci.1989, vol. 1;39-50.

3-A.O.A.C.Association of official analytical chemist.official methods of analysis.Microbiology Food Testing.Ch.,17 and Meat and meat Products.2005,17 $7^{\text {th }}$.ed. Gaithersburg, M.D.

4-ISO-.Microbiology of food and animal feeding stuffs. Horizontal methods for enumeration of micro-organisms. Colony count technique.2003, 4833-4843.

5-Zubain,A.I and Ibrabim,K.y. Isolation of Salmonella from slaughtered animals and sewage at Zakho abattoirfor,Kurdistan Region, Iraqi Res.Opin.Animal.Vet.Sci.2013,3:20-24.(IVL)

6-Taha,Z.M.A.Isolaton of salmonella among sheep flocks and sheep Abattoir in Duhok province. Msc.Thesis.Faculty of Vet .Med.2011, university of Duhok.(IVL)

7-AOAC.U.S.Food and drug Administration Bacteriological Analytical manual.1998,8thd.ADAC international USA.

8-APHA.America Public Health Association. Compendium of methods for the Microbiological Examination of Food .1998,3red.washinton.D.C.

9-ISO.Microbiology of food and animal feeding stuffsHorizontal method for the enumeration of micro-organisms. Colony count technique at $30 C^{\circ} .2002,(2263-2273)$.

10-Bean,N.H; Guolding,J.S., Angulo,F.J.Surveillance for foodborne disease outbreaks, United states. Surveillance Summ, 1996;45:1-66.

11-Meldrum RJ;Wilson,I.G.Salmonella and Campylobacter in United Kingdom retail raw chicken in 2005. J . Food Prot. 2007;70(8):1937-1939.

12-Molla B,Alemayehu,D.Salah W. Sources and distribution of Salmonella isolated from food animals, slaughterhouse personnel and retail meat products in Ethiopia: 1997-2002. Ethiop J Health Dev. 2003;17(1):63-70.

13-Mehrabian S,J; Jaberi E.Isolation, identification and antimicrobial resistance patterns of Salmonella from meat products in Tehran. Pak J Biol Sci. 2007;10(1):122-126.

14-Redmond E.C;Griffith,C.J.Consumer food handling in the home: a review of food safety studies. J. Food Prot. 2003;66(1):130-161.

15-Karmi,M.Prevalance of Salmonella in meat products. Global. Veterinarian.2013,(5);685-688. (IVL)
16-Karaboz, I. and Dinçer, B. Microbiological investigations on some of the commercial frozen meat in Izmir.Turkish Electronic Journal of Biotechnology,2002. Special Issue, pp: 18-23.

17-Food and Drug Administration (F.D.A).Food protection plan. Food and Drug Administration,U.S.Department of Health and Human Services.2007,Rockville.MD**(IVL: Iraqi Virtual Science Library). 